\title{
Historically Illustrating the Shift to Neoliberalism in the U.S. Home Mortgage Market
}

\author{
Ivis García \\ City and Metropolitan Planning Department, University of Utah, Salt Lake City, UT 60608, USA; \\ ivis.garcia@utah.edu
}

Received: 8 October 2018; Accepted: 12 January 2019; Published: 18 January 2019

check for updates

\begin{abstract}
This article takes a long view of the U.S. housing market; from its inception as locally owned and operated Building Societies, through one of the first major U.S. housing crises in the early 1930s, as well as through the prosperous and surprisingly stable post-WWII era the so-called "Long Boom" during Keynesianism. As labor shortages became more severe, accompanied by stagflation and the simultaneous urban, fiscal, and oil crises of the late 60s and early 70s, key sectors of the U.S. economy rallied to dismantle established Keynesian policies. While the new policies associated with laissez-faire economic liberalism certainly aided in the mobility of capital, the overall economy as a result of this neoliberal turn became increasingly unstable and inequitable. This article seeks to add knowledge to the neoliberalism theory. The author concludes, based on a historical case study of the Savings and Loans industry, that neoliberalism was not a deterministic overthrow of neoliberal ideologues but a haphazard response to the contradictions of Keynesian logic. It is only from a historical approach that we may be able to understand the current housing crisis, foster policy innovation, and allow for institutional change within the U.S. mortgage market sector.
\end{abstract}

Keywords: banking; financial institutions; industry; mortgages

\section{Introduction}

The effect of neoliberalism in the field of housing studies has gained considerable attention among scholars [1-4]. One might also find that the term is usually employed to convey frustration towards current political trends that affect housing policies [5,6]. Although it would be useful to understand shifts in economy and policy post-1970s, there is little in this "rascal concept," as Brenner, Peck, and Theodore (2010) put it, which is helpful in the way of illustrating policy shifts and institutional transformations before the 1970s [7]. That being said, this paper is based on Feliciantonio and Aalbers (2017) premise of why it is important to study the prehistories of neoliberal housing policies

if we want to understand contemporary neoliberalism, we need to understand how they build on and borrow from principles and policies developed in earlier periods. Since neoliberalism has not developed from one single, central control, the only way to understand the development of national and subnational neoliberalism is to focus on the prehistories specific to a country, region, or city [6], p. 13.

Academics traditionally have been more concerned with elaborating fuzzy concepts, and how policy actors (on the liberal or the conservative spectrum) contribute to a particular phenomenon, than with understanding processes using long term (more than a century instead of a few decades) historical approaches. At the same time, policy analysts seem to be more concerned with policy outcomes and how to affect them, than with how they came into being. Contrary to these short histories or non-historical but traditional approaches, the following article seeks to employ a more in-depth historical sensibility by illustrating the shift from pre-Keynesianism to Keynesianism to 
post-Keynesianism (that is, neoliberalism) in the U.S. home mortgage market. In this context, this paper attempts to contribute to the growing literature of neoliberalism theory. While neoliberalism is a recurring subject in housing studies, and often times a well-known Boogeyman of both academics and policy analysts, it is usually written about, taught, or retold using a sequence of events about actors powerful enough to change the course of history itself-for example, Fredrich von Hayek, Milton Friedman, Margaret Thatcher, Ronald Reagan, and other influential academics and policymakers.

Nonetheless, a small, but increasing number of post-Keynesian scholars (see for example Leo Panitch, Sam Gindin, et al.) have started questioning why stories of the aforementioned actors don't help us understand how Keynesianism, if it was such a sound housing policy ideal, was abandoned [8,9]. This article seeks to contribute to this particular literature strand. These scholars are diverting their attention from the participation of actors, and the emergence of the so call neoliberal turn, to the contradictions that existed within Keynesianism as a public policy ideal to begin with. Although this paper builds on previous studies of why and how the neoliberal policy came to be, it does so by studying the collapse of Keynesianism. This article will demonstrate how using historical case studies as a methodology—in this case, the U.S. home mortgage market from its inception—can help us understand how neoliberalism could be conceptualized as an unarticulated default policy response to the failures and contradictions within Keynesianism.

This paper is not trying to take "[ ... ] a view to the future" as Cole (2006) suggested, as much as it is concerned with creating an understanding of modern problems beyond the 1970s, and the discursive narratives surrounding neoliberalism and neoliberalization [10], p. 293. This paper finds narratives only looking at how the neoliberal era reinforces the powerlessness of actors, and undermines the ability of policymakers to intervene in public policy. In the end, the fundamental contribution of this article to the literature is that it was not the ideals admonished by anti-Friedmanites that were or are responsible for current entanglements between the polity and its economic and theoretical base. Instead, by utilizing a historical case study of the Savings and Loan industry, this article demonstrates that the process of neoliberalization would be better understood as a collapse of Keynesian technocraticism than an overthrow of it. The paper concludes by arguing that expanding our historical analysis from just the neoliberal era to previous eras, might empower policymakers to present alternative policy solutions. Moreover, this article proposes that understanding history can help us not to romanticize the past or mystify the political-economy in its current state of being, on the contrary " $[\ldots$... a sound grasp of the past" as Cole (2006) put it, it can offer a way of moving forward and a glimpse into future possibilities [10], p. 293.

This article is organized as follows. First, we define neoliberalism and neoliberalization. Second, we tell a brief history of neoliberalism introducing the reader to leading thinkers on the topic including Milton Friedman, Friedrich von Hayek, Harvey, among others. Third, the methodology, a historical case study along with its limitations is explained. Fourth, a history of the rise and fall of Savings and Loans (S\&Ls), from their inception in the early 1930s until they began to crash in the 1980s, will be presented. This history is divided into three eras-pre-Keynesianism, Keynesianism, and post-Keynesianism (i.e., neoliberalism) - with the objective of outlining the transition between these policy frameworks as they manifested themselves within the U.S. home mortgage market. The paper ends with the discussion and conclusion sections where the contribution to the neoliberalism literature, and the implications of this case study for theory and for the public at large is emphasized.

\section{Defining Neoliberalism}

It would undoubtedly be best to begin this article with a discussion of what is meant here by "neoliberal," as it is often a contentious and unrefined notion that is rarely defined and is, instead, left as an overlying concept. While this is true, the article defends the existence of a "neoliberal" overlying thought or ideology even while the term itself lacks any common understanding. This article shows that, perhaps, the lack of a common understanding is more appropriate than any literal and 
rigid definition would be. To be "neoliberal," to live in an age of "neoliberalism," or to witness the "neoliberalization" of regulatory praxis, is not to witness the implementation of rigid ideological and theoretical structures.

On the contrary, it is to be, to live, or to see the development of an overlying ideological and theoretical concept as it is instituted into the policy framework. The framework is established not evenly, and not rigidly, but most often haphazardly. It is structured within the constraints of, and only in historical context to, previous policy frameworks. It is then appropriate to perceive "neoliberal" as the fluid and uneven implementation of overlying ideals and theories. These ideals can be contradictory and ineffectual, because they are exercised as a social movement and as a set of political practices [11].

If we are to understand "neoliberal," not as a rigid policy framework, but as a slipshod regulatory phenomenon: how might we go about understanding its development? That is, of course, assuming we could call it development. How do we decide what "neoliberal" is and what it's not? How do we avoid using the term, as Thorsen and Lie (2006) put it, as "a generic term of deprecation describing almost any economic and political development deemed to be undesirable"? [12], p. 9. Furthermore, even if we were to accurately capture and define the logic of a "neoliberal" sentiment: how might we go about reconciling the vast chasm of contradictions between the ideals of "neoliberalism" and its policy implementation, through a process of "neoliberalization"?

To this end, the same question might be asked of the term "Keynesianism." Keynesianism was not, after all, a rigid policy framework, any more than neoliberalism may be, even while it enjoys extensive usage without the same degree of scrutiny. However, for the sake of argument, we will set aside any linguistic contradictions that might be implicated by such a term to construct a simple model of neoliberalism, which, while probably easy to receive, still begs far too many questions to be answered here.

It might be useful to present a definition of neoliberalism, even while recognizing that its implementation may run contrary to its ideals. Perhaps the best definition of neoliberalism ('best' because it demonstrates not only the literal interpretation of neoliberal ideology, but also alludes to its transitory and imprecise nature) comes from David Harvey (2005), in his book titled A Brief History of Neoliberalism:

Neoliberalism is in the first instance a theory of political, economic practices that proposes that human well-being can best be advanced by liberating individual entrepreneurial freedoms and skills within an institutional framework characterized by strong private property rights, free markets, and free trade. The role of the state is to create and preserve an institutional framework appropriate to such practices. The state has to guarantee, for example, the quality and integrity of money. It must also set up those military, defense, police, and legal structures and functions required to secure private property rights and to guarantee, by force if need be, the proper functioning of markets. Furthermore, if markets do not exist (in areas such as land, water, education, health care, social security, or environmental pollution) then they must be created, by state action if necessary. But beyond these tasks the state should not venture. [13], p. 2

The 'normal' practice in discussing the progression of neoliberalism has been to outline its historical implementations, which many academics are familiar with and so this article will only touch on the story briefly. Though, this article will also be incorporating some more recent work on the topic to illustrate the continuing process of neoliberalization. The story, presented in the next section, presents a far too linear approach to the development of neoliberalism, and so we will only be using it here to aid in conceptualizing the popular synthetic framework.

\section{Popular History of Neoliberalism}

Briefly, the history of neoliberalism is often laid out in the following way. Upon the publication of his book, The Road to Serfdom (1944), a number of like-minded economists joined Friedrich von Hayek at 
the Mont Pelerin resort in Switzerland [13-15]. Among other notable attendees were Milton Friedman, Ludwig von Mises, Karl Popper, etc. [15]. This group, dubbed the "Mont Pelerin Society," feared that governments were undermining freedoms. They argued that though the government claimed to benefit the public, they were actually creating tyrannous authoritarian regimes. In other words, "the enemy is clearly government" [1], p. 2. Spread of the ideals held by these regimes needed urgent replacement by free societies, governed by the freedom of the invisible hand of the market as opposed to the tyrannous arm of government.

Some of the adherents to the classical liberal ideals of freedom, a freedom they perceived to be dependent on freedom in the market, as expressed by the Mont Pelerin Society, came to dominate a number of upper-level positions within academia [13]. Most notably, Milton Friedman became a professor of economics at the University of Chicago, a position he used to propel the ideals of the Mont Pelerin Society into academic discourse. Friedman and his disciples at the so-called, "Chicago School" sought to teach these ideals to academics in the U.S. and other countries in the global capitalist crises of the 1970s [15].

The Chicago School, led by Friedman, trained a number of economists from the Catholic University of Chile- these Chilean economists came to be known as the "Chicago Boys." The Chicago Boys returned to Chile, and with the help of an American led coup against the democratically elected-and perceivably Marxist—government of Salvador Allende [13,15]. The Chicago Boys were able to implement the ideals, many for the first time, of Friedman and the Chicago School. The implementation of these reforms, however, were incredibly unpopular among Chilean people, and were only enforced by the U.S.-backed dictator, Augusto Pinochet whom ended up killing thousands, torturing tens-of-thousands, and inspired the exodus of hundreds-of-thousands of his opponents.

Despite the carnage and brutality, the neoliberal experiment in Chile was, by-and-large, deemed a success by the Chicago School and acted as a catalyst for continued experimentation and entrenchment of neoliberal policy ideals in progressively wider arenas. Most notable amongst the new experimentation sites were in response to New York City's fiscal crisis of the mid-1970s [16], and the Mexican default of the early 1980s [13,17]. It is important to note here that the utilization of neoliberal policies within periods of crisis is seen by many as an essential element of the neoliberal project [18].

This process of experimentation, legitimization, and institutionalization of neoliberal regulatory reforms presents itself, like Brenner, Peck, and Theodore (2010) demonstrate in Figure 1, as a "variegated form of regulatory restructuring" [7], p. 330. The conceptualization here is that as government "roll back" from the socioeconomic sphere in the 1970s, by the 1990s the state had "roll out" new housing policy based on neoliberal thought [5]. However, while much of the established literature has aptly and eloquently captured the progression of neoliberalism from its early experimental phase to its current pseudo-monolithic doctrinal discipline, few have as eloquently captured the shift from Keynesian regulatory policies in terms of real changes in specific sectors from the perspective of disintegrating proto-neoliberal (post-Keynesian) regulatory policies.

While there are a number of points to be argued for or against in the narrative above, in the interest of avoiding a straw-man argument, the narrative should not be understood as anything other than a relative approximation of the discursive and conjectural narrative being used to highlight major points in the development of neoliberalism. Were this rough framework taken as a literal interpretation, it would run the risk of undermining a whole host of significant works on essential topics.

Nonetheless, in the interest of creating some clarity where the above narrative only creates confusion, the remaining portion of this work will be dedicated to illustrating the apparent shift from Keynesianism to neoliberalism as it manifested itself within the U.S. home mortgage market. By doing this, the article hopes to create a rough, but nuanced, portrait of the transitionary period between technocratic and non-technocratic managerial policies domestically. The article follows this historical review with a concluding remark on the importance of using a long-term lens to assess the historical trajectories of the U.S. mortgage market. 


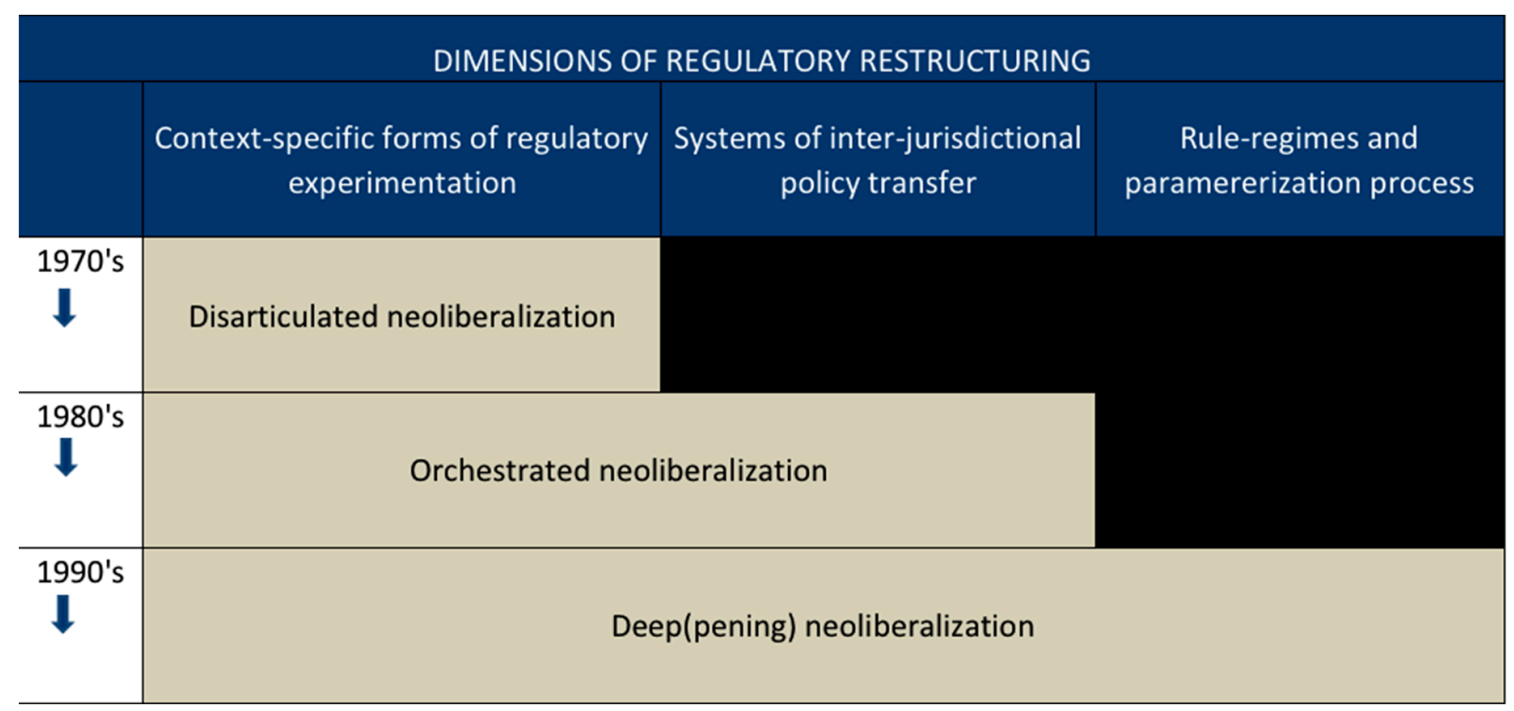

Figure 1. Dimensions of Regulatory Restructuring [7].

\section{Methods and Limitations}

This article employed a historical case study methodology to understand the progression of neoliberalism $[2,10,19]$. As such, it relied on an understanding of time and eras in the long-term or "a durée, a continuous flow of conduct" as Anthony Giddens once put it [20], p. 3. News clips, legislative acts, and historical texts such as Rosenthal (1891), Dexter (1889), Morman (1920), Clark (1924), etc. were reviewed to understand the rise and fall of Savings and Loans (S\&Ls) from the 1930s to the 1980s [21-24]. In order to illustrate the fall of the S\&Ls industry, data publicly available from 1945 to 2000 was gathered from the Federal Reserve Board, Flow of Funds Accounts: Annual Flows and Outstanding's.

Historical case studies rely on narrative, synthesis, and causal argumentation also known as "path dependency" $[10,25,26]$. In this particular case, I argued that neoliberalism was a response to the fall of Keynesianism. As illustrated by the transformation of the U.S. mortgage market from primarily S\&Ls into mainly commercial banks, we can see that neoliberalism became more prevalent not because of an ideological neoliberalist coup d'état, but because Keynesianism like all systems_as described by Karl Marx (1977), David Harvey (2005), and other critical theorists—runs into internal contradictions that cause it to collapse $[13,27]$.

It is also important to note here what are some of the limitations of historical case study methodologies. First, case studies cannot be generalized. Ideally, more case studies beyond the S\&L could be included in the future to broaden the understanding of how neoliberalism came into being, as argued by Feliciantonio and Aalbers (2017) [2]. Another disadvantage is that, because historiography relies on the interpretation of the researcher; therefore, one could not control for bias. Finally, an epistemological limitation was the lack of internal validity.

\section{The Rise and Fall of Cooperative Home Mortgage Lending}

The following sections outline the rise and fall of Savings and Loans (S\&Ls), who were the largest lenders of home loans from the Keynesian era until they began to crash in the 1980s. In the paragraphs below, this article argued that the collapse of S\&Ls was more complicated than how it is presented in the often-repeated, yet overly-simplistic, popular narrative of academics and policy analysts. To illustrate this point, Representative Barney Frank stated the familiar narrative publicly: "30 years ago if you went to get a loan for a home, the person lending you the money expected you to pay him or her back ... We've since developed securitization whereby the people who make the loan are no longer at risk if there's a failure to repay" [28]. While the concept has become a part of the popular narrative, it is rare for any substantive analysis to take place after the statement is made. 
To help contextualize how local, ostensibly accountable, lenders came to transcend their individual exposure to risk through the securitization of home lending, this paper "reassess the political and historical roots of neoliberal policies" [2], p. 13. Subsequently, the article argues that it wasn't that S\&Ls who dutifully served the population's interests so well as local lenders of mortgages suddenly became overrun by charlatans and hucksters (as the popular narrative of the time indicated), but that there were significant contradictions between the S\&L structure and the broader economy in general which caused their collapse. It is the structures created by capitalism that embody the contradictions of capitalism.

This article broadens this narrative by putting the development of neoliberalism into context with the demise of S\&Ls. This article demonstrates that the collapse of local lending institutions was not due to a grand neoliberal coup, or the fault of some lofty, misguided, regulatory policy ideal, but was a response to the collapse of the Keynesian/New Deal regulatory structure. This article is then dedicated to illustrating the shift from pre-Keynesianism to Keynesianism to post-Keynesianism (i.e., neoliberalism), as it manifested itself within the U.S. home mortgage market. To demonstrate this shift, I conducted a literature review on the U.S. mortgage market from the 1830s (or from the inception of what developed into the thrift industry) to its decline (when we start seeing the rise of neoliberalism). By taking a longitudinal assessment that covers more than a century, as opposed to a few decades, the article hopes to show that the demise of Keynesianism in the U.S. was not predicated on the rise of neoliberal ideology, but that neoliberalism was a response to the collapse of Keynesianism.

\subsection{The Pre-Keynesian Era}

Known by many different names-Building Associations, Co-Operative Savings and Loan Associations, Co-Operative Banks, and so forth-but what most commonly became known as Building and Loan Associations (or, as an industry in general, thrifts) grew to become the predominant mortgage lenders in the early years of U.S. history [22]. The first Building and Loan in the United States was the Oxford Provident Building Association, established in Frankford, Pennsylvania, on 3rd January 1831 [22,29-31]. The organization was solely owned by depositors and was restricted to service only those within five miles of Frankford, a suburb of Philadelphia.

Oxford Provident and its predecessors differed substantially from their commercial banking counterparts. Commercial banks operated as for-profit corporations whose membership had little recourse to the institution, with the obvious exception of being able to withdraw their funds. Building and Loans, on the other hand, were not-for-profit, geographically restricted, owned solely by their shareholders, and did not take in demand deposits, but instead issued and then dispersed shares from the members' own savings (in the form of stock), as opposed to loans. Most importantly, Building and Loans were democratically held and led. All shareholders who had a stake in the association could voice their opinion and were arranged such that no one shareholder or group of shareholders could commandeer the organization.

There is no separate, preferred class to be benefited at the expense of other members.

Even though a capitalist becomes a member and subscribes for a large number of shares he can derive no benefit or advantage on each share that cannot be commanded by the humblest member [21], p. 29.

The egalitarian, cooperative, and democratic nature of thrifts, as well as their simple method of formation and easy maintenance, allowed the thrift model to spread quickly. The cooperative nature of the thrift structure meant that, while borrowers paid interest against their borrowed funds, the whole of the association's membership would take an even share of the institution's profit. As a historian researching thrifts noted, "Borrowers in reality, therefore, receive interest to a limited extent on their own debts, a result attributed entirely to the principle of cooperative credit" [23], p. 174.

While the thrift structure quickly spread throughout the country, many states were slow to incorporate them through legislative acts formally. Thrifts were, after all, the only lenders who could or 
would lend to their membership, even while they were contributing only small amounts into the fund. As Clark (1924) writes:

[I]t is not to be wondered at that organizations are neglected by economists generally when they have as their principal purpose the collection of a few cents per month from persons with small incomes, and expect to use these small sums for the purpose of upbuilding the home life of their community [24], p. 621.

In 1886 the first "national" building and loan association was formed in Minneapolis, Minnesota, and in only a few years, national thrifts had spread throughout the country [32]. Offering similar services as "local" thrifts, national institutions established themselves with branch offices around the country, took deposits from these local branches, and redistributed funds where necessary by mailing money from one branch to another. The nationals, however, operated as for-profit associations and held few of the democratic characteristics which were emblematic of their local counterparts. Given the nationals' for-profit nature, coupled with the fact that their organizers expected weighty returns on their investments, nationals' operating expenses tended to run at three or four times that of the traditional (local) Building and Loans. As such, nationals

must always expand a large proportion of their receipts for running expenses, and can never be in any real sense coöperative ... [They] are anomalies, because they are not and cannot be mutual in character or democratic and economic in management [32], pp. 78-79.

While borrowers and savers were attracted to the national associations' claims to generate returns three or four times that of local associations [33], the claims proved to be little more than smoke and mirrors. Nationals did not guarantee high levels of returns, but implied them based on requirements for a set number of monthly payments to be made before funds could be withdrawn. If one wished to withdraw funds before maturation, or failed to make payments on time, however, nationals would charge exorbitant fines and even impose a "tontine" arrangement where a depositor would forfeit all of his or her funds simply for withdrawing from their account. One study showed that nationals were relying on as many as fourteen different fines and fees for revenues [33].

For these reasons, nationals came under constant criticism from the established local Building and Loan Associations. Many charged that these nationals were not Building and Loans at all, but were instead a scam exploiting the good name of Building and Loans while offering inferior and usurious products to their customers. Seymour Dexter, who later became the first president of an organization which sought to challenge nationals while protecting locals, once criticized these institutions for "roping-in"

the ignorant and unwary borrowing stockholders by describing the merits of the genuine Co-operative Savings and Loan Association scheme, and by representing that, while they seem to be paying a large premium in excess of legal interest weekly or monthly, they will get it back in the dividends added to their stock, and that in the end, their loans will not cost them more than legal interest, and possibly even less. The borrower sooner or later will find that he has been deceived, that he is in a net from which he cannot extricate himself without a severe loss [22], pp. 330-331.

Despite their flaws, nationals became highly successful and propagated throughout the country in only a short time; and their success stressed the established local Buildings and Loans. With increasing competition, local thrifts contributed to the establishment of a lobbyist organization dubbed the "U.S. League of Local Building and Loan Associations" (which later became the U.S. League of Savings Institutions-more often referred to as "the League"), and political infighting between nationals and locals became commonplace. While nationals won the occasional battle, the League was successful in lobbying for regulations against them-including caps on executive pay and limiting the amounts which nationals were allowed to charge for fines and fees. The new rules severely handicapped 
nationals and, in a crisis, and real estate crash that lasted from 1893 to 1896, the national Building and Loans collapsed under their own weight.

The collapse of the nationals affected locals in a number of ways, not the least of which was a loss of public confidence in Buildings and Loans in general. An 1896 article from the Financial Review and American Building Association News states that, "it will be years before it will be possible to establish a genuine building and loan association in a community after the name of building associations has been besmirched and prostituted, and brought into grave disrepute through the action of schemers who have run these bogus concerns" (as cited in Mason 2004) [33], p. 28. Though their name had been tarnished in the public trust, perhaps the most important implication of the nationals crash was the realization within the thrift industry that they could use legislation and regulation to curtail competition and secure their stability and dominance as mortgage lenders.

\subsection{From Pre-Keynesianism to Keynesianism}

The first three decades of the 20th century in the United States were plagued by a series of "financial panics," as they were called, which made it increasingly difficult to legitimize the banking system as a whole. The panic of 1907 provided the impetus for the creation in 1913 of the Federal Reserve System. Though a central bank had been created in 1811, which failed as Madison took office, and again in 1816, only to be dissolved twenty years later, this time the Federal Reserve System stuck. The Federal Reserve System (or, simply, "the Fed") served to strike and manage the nation's currency as well as oversee each of the twelve local reserve banks, which were in turn responsible for overseeing commercial banks within their respective regions. While the Fed certainly helped to create the necessary elasticity for money held within its member banks, and could more rapidly deploy funds from one bank to another in case of a "run," these panics continued until they culminated in the Great Depression. To stem the tide of runs on banks, to create some semblance of stability within the banking system in general, it seemed inevitable that either banking would be scrapped outright or some new regulatory structure would have to be created to ensure its relative stability. For the Fed and for commercial banks throughout the country, this stability came in the form of federally-backed depositor insurance through the newly formed Federal Deposit Insurance Corporation (FDIC), which was established by the Banking Act of 1933.

Similar to the restructuring of commercial banking, legislators, and the League collaborated to formalize the thrift regulatory structure - this formalization process merged the Building and Loans of old into a new (and, to us now, more familiar) Savings and Loans (or, S\&Ls) structure. The first significant legislation for thrifts came with the Federal Home Loan Bank Act of 1932, which established the Federal Home Loan Bank Board (Bank Board), and a system of twelve regional Federal Home Loan Banks (FHLBs) that would serve as wholesale lenders to their regional thrifts. Each of the 12 regional FHLBs were owned by their member thrifts and were regulated and supervised by the central Bank Board in Washington, D.C. Local thrifts were required to invest capital in the FHLB serving their region in return for stock in the FHLB - for which they would periodically receive dividends from FHLB profits and were allowed to elect two-thirds of the FHLB's board (the other third being elected by the Bank Board in Washington, D.C.).

In 1934, the National Housing Act created the Federal Savings and Loan Insurance Corporation (FSLIC) to provide deposit insurance in a similar fashion to commercial banking's FDIC. The FSLIC covered all federally chartered thrifts, while state-charted thrifts had the option to buy into coverage. The National Housing Act also established the Federal Housing Administration (FHA), which was charged with the responsibility of regulating the rate of interest and the terms in which mortgages would be insured under the FSLIC. The FHA was also created to provide a structure to accommodate mortgage lending for low-income, but otherwise qualified households. In 1944, the Veterans Administration (VA) furthered such housing efforts to include GIs returning from WWII.

Lenders, however, remained reluctant to invest in the FHA, and in 1938 an amendment to the National Housing Act created the Federal National Mortgage Association, or "Fannie Mae." Fannie 
Mae was established to purchase FHA-insured (and later included the VA-originated) mortgages and to bundle a group of these mortgages together (a process now known as "securitization") into packages termed "Collateral Debt Obligations" (CDOs). CDOs managed by Fannie Mae were large pools of bundled mortgages, which were paid for by borrowing from foreign and domestic investors and subsidized by the U.S. government. This new system became known as the secondary mortgage market.

The basic notion of a securitization pool is similar to the concept of insurance. As large amounts of funds (in this case mortgages) are pooled together, the risk of having to pay those funds to claims (or in the case of housing when a mortgage is defaulted upon) is spread across the entire pool. In this way, the aggregate pool of mortgages can compensate for the risk of default associated with any given mortgage. Fannie Mae was the pioneer of the secondary mortgage market, and for the first 30 years of its existence operated as a monopoly over it.

As depositors no longer needed to worry about the security of their savings within thrifts, the new federally-backed insurance fund-the FSLIC - allowed lenders to loan for longer periods of time. This reduced overall monthly payments for mortgages, and in turn, allowed for a larger portion of the U.S. population to acquire mortgages. However, these mortgages came with increasingly longer lengths of contract. By 1947, average mortgage contract lengths "had risen to 15.2 years from the 10.8-year average contract length prevailing in 1930. This trend toward longer contract lengths continued through the postwar period, and by the late 1950s, the average maturity of mortgage loans at S\&Ls was in excess of 20 years" [31], p. 1109. While the newly formalized Savings and Loan structure worked to facilitate massive post-war growth in housing, the increase of contract lengths created little more than "the illusion of home ownership through the reality of debt" [34], p. 83. Simply put, the ideological and political construct of a "homeowner's society" was created through the financialization of housing [2], p. 3. Burgeoning contract lengths also created a major structural flaw which eventually led to the collapse of the thrift industry as a whole, a subject we will discuss in the following section.

\subsection{From Keynesianism to Neoliberalism}

While there are indeed discussions to be had about urbanization, gentrification, segregation, suburbanization, unequal, often racist and sexist lending practices, the period between the New Deal and the late-60s, regarding mortgage finance, remained mostly unremarkable [35]. In only a short period, the thrift industry-dominated by the newly created Savings and Loan structure-came to originate and service the majority of U.S. home loans. Where the S\&Ls lacked a profit motive (as in lowto moderate-income mortgage lending) the federal government-through the FHA, the VA, and Fannie Mae-picked up a significant portion of the slack.

This period was also one of sustained growth for the economy as a whole. Standards of living in the U.S. increased for the majority. Even African Americans-who have traditionally been left out from the benefits of any economic growth-had opportunities to join the ranks of the working- and middle-class (for a time, anyway). The post-war growth was so significant, in fact, that it has often been referred to as the "Long Boom" by commentators. However, by the late 1960s, with increasing foreign competition and the capacity for a reliable and well-organized labor force to have redress to capital, both in the workplace and through the political process, it was becoming clear that the regulatory and legislative doctrines, which brought on the Long Boom were now impeding capital's continued expansion [36].

It is from this vantage point that we can begin to see an impetus for the "depoliticization" of economic management [37]. The interventions of policymakers could "be canceled out, overwhelmed by unexpected effects cascading across social networks" [1], p. 5. With the rapid expansion of post-WWII growth, Keynesianism presented a useful regulatory regime. Nonetheless, when foreign competition and a strong labor movement were coupled with a series of oil supply shocks in the early 1970s, corporate profitability shrank by $40 \%$ [38]. As profits were squeezed, possibilities for growth 
were constrained by a lack of new conduits for investment. In response, capitalists raised prices, and in turn, laborers demanded higher wages. This process, the so-called "wage-price spiral," aggravated the inflationary pressures which plagued the 1970s [39,40].

As mentioned previously, S\&Ls were-throughout the Long Boom-taking on mortgages which required increasing spans of time before maturation. These mortgages, however, had fixed interest rates which made it so that an S\&L had to gamble on a belief that the overall economy's inflation rate would stay well below the interest rates attached to their mortgage holdings. That is, if the rate of inflation were to hold steady at $1 \%$ for the entire length of a $5 \%$ fixed-rate, 30-year mortgage, which would mean that the S\&L was making $4 \%$ profit per year on the outstanding portion of the mortgage (this is, of course, ignoring any amortization schedule). If the inflation rate jumped to $12 \%$, as it did in 1974, this would mean that the S\&L was losing 7\% on the loan. Worse yet, S\&L also had to pay interest on the depositor savings accounts, providing the basis for the loan in the first place. So, if our S\&L was paying $1 \%$ to the savings account, and losing $7 \%$ on the loan from inflation, our S\&L was in the red for $8 \%$ on that mortgage.

To add another dimension to this problem, S\&Ls were in competition with commercial banks (and others) for their deposits in the first place. If they were to lower the amount of interest paid to a customer's savings account, the customer would simply withdraw their funds and take them to a bank (or even another S\&L) that was paying out higher returns. This, the process of removing funds from one institution and depositing them into another to garner higher yields is known as "disintermediation." The waves of disintermediation had become such a problem for S\&Ls that in 1973, S\&Ls were gaining and losing billions in deposits every month-in 1979, the worst of these waves, the thrift industry as a whole lost over half of their deposits [33].

Volatility in prices, interest rates, inflation, and disintermediation throughout the '70s brought much of the thrift industry to the brink of collapse. In August of 1979, Paul Volcker was appointed by then-president Jimmy Carter to head the Federal Reserve Bank at a time when inflation had been spiking even though unemployment levels remained fairly low. Late into the night on Saturday, October 6th, 1979, Volcker announced to the press that he would reverse the Fed's standard practice of focusing on interest rates to curb inflation and opted instead to tighten the money supply while "floating" the federal funds rate. The change was dubbed by political commentators as the "Saturday Night Massacre," and resulted in a rapid spike in interest prices and ultimately caused a two-year recession. The move, however, did stop the uncontrollable inflation.

By the time Reagan took office in 1981, the Depository Institutions Deregulation and Monetary Control Act of 1980 had removed interest rate ceilings on savings accounts for banks and thrifts; allowed commercial banks to merge; and allowed thrifts to create checking accounts, while also allowing them to open statewide branches and to further diversify their portfolios by holding up to $20 \%$ of their assets in consumer loans and corporate bonds [30]. The process of homogenizing and merging the S\&L structure into the increasingly aggressive commercial banking apparatus was well underway long before neoliberalism is said to have existed.

Even with deregulation and moderated levels of inflation, however, thrifts remained sluggish. By 1981, new mortgages issued by thrifts had dropped to half of what they had been in 1978. By the end of 1981, the thrift industry had net losses totaling over $\$ 4.6$ billion, and thrift failures reached levels not seen since the Great Depression [33].

In 1982 Congress approved the Garn-St. Germain Depository Institutions Act, which expanded assets that could be held by thrifts and made it easier to shift from mutual ownership to stock ownership (otherwise known as "mutual-to-stock conversion"), and even allowed thrifts to use the term "bank" in their title for the first time [33].

The Bank Board - in yet another of the many re-regulations of 1982-further allowed thrifts to augment standards for their financial statements prepared using "Generally Accepted Accounting Principles" (GAAP) with the (often more liberal) "Regulatory Accounting Principles" (RAP). Under RAP, losses from the sale of an asset could be spread out over ten years, while GAAP would have 
required that the loss be recognized immediately [33]. Where GAAP was more lenient than RAP, however, they would adopt the former [41]. Accounting schemes allowed thrifts and their regulators (the Bank Board) to "paper over" existing problems [42,43]. This was so much the case that in 1982, according to GAAP standards, " 415 thrifts with $\$ 220$ billion in assets were insolvent." According to RAP standards, "the Board reported that only 71 thrifts with $\$ 12.8$ billion (US billion) in assets were insolvent" [33], p. 223.

Figure 2 "Changes in Thrift Market Share" which uses data from the Federal Reserve Board, Flow of Funds Accounts: Annual Flows and Outstanding's shows how even though mortgage debt was increasing nationally until 1979, the share held by the S\&L industry decrease precisely at around that time. In Figure 2, we also see how after the collapse of the S\&L industry the mortgage debt market becomes more unstable, going up and down as explained by Mason (2004) [33]. Figure 3, "Relative Change in Home Mortgage Market Share" shows how as thrifts decline other mortgage institutions such as Federally Related Mortgage Pool and Asset-Backed Securities started to increase. Figure 3 also shows how in the mid-1970s the percentage of mortgages made by commercial lenders increase while mortgages made by thrifts declined.

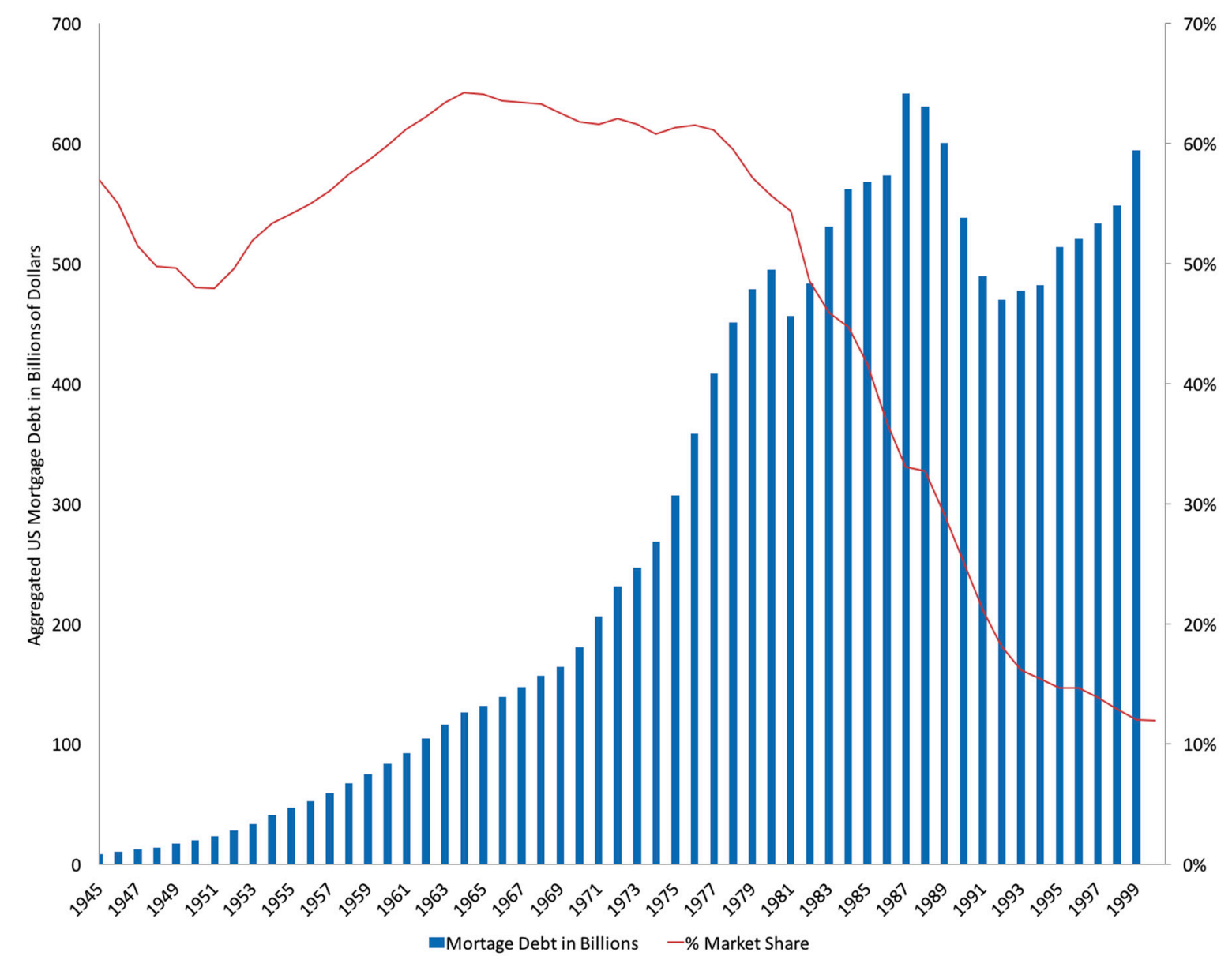

Figure 2. Changes in "Thrift Market Share", which uses data from the Federal Reserve Board, Flow of Funds Accounts: Annual Flows and Outstanding's.

The accounting schemes, the instability, and the lack of a rationale for maintaining local mortgage lenders in an increasingly global marketplace, severely undermined the capacity for S\&Ls to continue in any sustainable fashion [30]. As thrifts slowly (and painfully) imploded, they were taken over by schemers and scammers seeking to make a quick buck. This environment culminated in a grand bust of the thrift industry, which, by the time S\&Ls entirely dissolved in the mid-90s, was little more than a 
large-scale Ponzi scheme. This, unfortunately, is the lasting legacy of the thrift industry. Their demise washed away any memory of democratic, local, or cooperative mortgage lending ideals.

Relative Change in Home Morgage Market Share

Source: Federal Reserve Board, Flow of Funds Accounts: Annual Flows and Outstandings, from 1964-2000, September 18, 2001

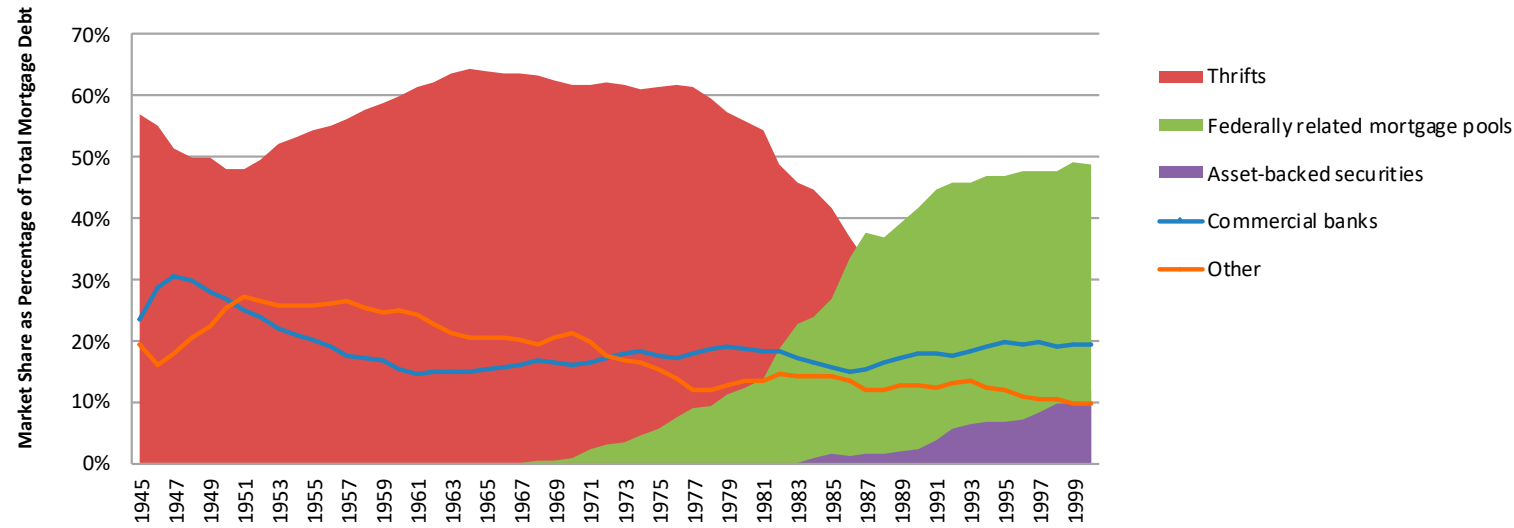

Figure 3. Relative Change in Home Mortgage Market Share. Data source: Federal Reserve Board, Flow of Funds Accounts: Annual Flows and Outstanding's.

\section{Discussion}

This article has presented a historical case study narrative as suggested by Feliciantonio and Aalbers (2017) and Cole (2006) by way of a methodological approach that could be further employed in the neoliberalism literature $[2,10]$. Based on a review of the rise and fall of the Savings and Loan industry, to better understand the transition from pre-Keynesian to Keynesian to post-Keynesian (or neoliberal) eras. As discourses surrounding concepts of neoliberalism sink deeper and deeper into esoteric and scholastic debates_-for examples, see Brenner et al. (2010) or Harvey (2005)—it has become increasingly essential to re-frame some of the real-world elements of our current era's political and economic constrictions within a less rhetorically charged, more practically oriented, and readily palatable, historical narrative $[7,13]$.

This paper has contributed to the literature on neoliberalism by showing that neoliberalism could be better understood as the fall of Keynesianism. Neoliberalism was a default response that came from the old shelves of classical economic liberalism when Keynesian policies were not affecting any longer. When Volcker opted for floating the federal funds rate classical liberalism had a positive effect; this victory was the beginning of other neoliberal policies which will be implemented ideologically. From this brief analysis of the U.S. mortgage market, we might gain some insight into how and why neoliberalism came into being. It certainly cannot be attributed to the rise of one ideological movement any more than it can be attributed to the collapse of another. In fact, it might be better to understand the rise of neoliberalism as the collapse of Keynesianism. However, as Karl Marx (1977) once wrote:

No social order is ever destroyed before all the productive forces for which it is sufficient to have been developed, and new superior relations of production never replace older ones before the material conditions for their existence have matured within the framework of the old society ... Mankind thus inevitably sets itself only such tasks as it is able to solve since closer examination will always show that the problem itself arises only when the material conditions for the solution are already present or at least in the course of formation [27].

While Marx was discussing the transition from feudalism to capitalism in the above quote, it indeed maintains an air of truth even when applied to transitions between different regulatory regimes within a capitalist system (and, perhaps, within any system in general).

In the same social evolutionary spirit-and by evolution, I mean change and not necessarily progress-it might be said that the crash of the nationals back in the late 1800s was a significant 
contributor to the collapse of the Savings and Loan industry in the early 1990s. Were it not for the experience of competing with nationals, local thrifts would have had little reason to ban together and create the U.S. League of Building and Loan Associations. Were it not for the League solidifying the thrift structure and institutionalizing their ethos into the New Deal regulatory framework, no alternative framework to commercial banking would have been available during the Great Depression. Were it not for the implementation and institutionalization of the League's efforts, there would have been no S\&L structure to fight for. No League, no S\&Ls. No S\&Ls, no mismatch between mortgage lengths and consumer deposits available on demand—and therefore no crash of the Savings and Loans in the 80s and 90s.

In taking a long view of the past, the S\&L case study shows path-dependency when applied to institutions - that is, customs and mores (pace Veblen 2009) [44]. By path-dependency, as historical methodology, I mean that a continually unfolding set of processes marks the "[ ... ] trajectories of social, economic and cultural change" [10], p. 286. In this vein, we might also conclude that in each of these crises, in each collapse that eventually led to a significant overhaul of U.S. regulatory policy, had there been at the time of these crises an alternative framework presented to that of the neoliberal, we might have achieved remarkably different results. If we follow this train of thought, we might assign at least part of the blame for the rise of neoliberalism squarely on the shoulders of those on the left who refused to budge from (rapidly antiquating) Keynesian ideals.

Even today, much of the mainstream left is stuck on reinvigorating the perceived growth during the Keynesian era-here we could name some of the authors mentioned above including Harvey (2005), Klein (2004), Brenner et al. (2010), and others [7]. I see this as the opposing point of view because it assumes a takeover of neoliberalism and not a collapse of Keynesianism. The problem with the many proponents of "let's go back to Keynesianism" is that they do not recognize the contradictions of Keynesianism some of them which resulted in inequitable practices. The advocates of Keynesianism, neo-Keynesians, seem to be experiencing amnesia regarding banking policies in communities of color. They seem to forget that the FHA refused to offer mortgages to African Americans and other minority communities. Furthermore, it was the Bank Board who, in 1935, requested maps from the government, which would show all of the areas where Puerto Ricans, Blacks, and others lived to establish zones where their lending would not touch [45]. Thus, the legalization and formalization of racism were embedded in their process of redlining. Thrifts segregated blacks into inner-city slums, while helping to create vast sprawling suburban tract housing for middle and upper-class whites.

Another point in favor of my argument is that by adopting a historical approach that doesn't romanticize the past, academics and policy analyst can adopt a more critical and nuanced understanding of Keynesianism. Tracing and problematizing the past might also help us create more equitable housing programs, policies, and practices in the near future. Through embracing a historical sensibility, housing studies can move "[ ... ] towards an analysis focused on primary evidence about specific moments, movements, ideas or epochs so that surprising discoveries can challenge conventional wisdom, and in the process present a more provocative view of how housing systems can change and new policies emerge" [10], p. 286.

To move forward, to abandon neoliberalism for some "other" guiding regulatory principle, the left must also abandon the ideals of orthodox Keynesianism. While it may be true that the government should adopt counter-cyclical spending policies during the valleys of the business cycle, for example, this is becoming increasingly impossible within the neoliberal regulatory precept, and therefore any argument for counter-cyclical spending renders itself a moot point. Alternative frameworks have to be presented to the neoliberal framework for any substantive change to occur. I believe that this is another advantage of understanding that Keynesianism fell apart because of its own contradictions, different from other arguments, it helps up to look into the future by looking at the part, meaning that we can find solutions. However, this is further complicated by the policy discourse (the counter argument), which seeks to undermine all alternatives. While a discussion of these alternatives is outside the scope 
of this particular work, it should become increasingly clear that it is fundamentally important to scrap the old notions and rhetoric of the New Deal era for an entirely new regulatory ideal to take place.

\section{Conclusions}

What theoretical implications might be gleaned from the preceding historical narrative on the rise and fall of S\&Ls as an exploration of contemporary policy concerns? And, how the use of a historical case study contributes to the literature on neoliberalism and neoliberalization? First, the belief that a deterministic overthrow of benevolent policies by neoliberal ideologues is an untenable one. The fall of S\&Ls clearly had more to do with an incapacity for the presiding structures to conform to a changing economic environment; specifically, the institutional structure of the S\&L industry was predicated on a growing economy - when the economy had reached its limits of growth, the structure faltered and eventually failed.

This failure represented a broader problem with regulatory policies being created in periods of growth and being founded on principles of consistent, unending economic expansion, in general. When the growth of the capitalist economy inevitably subsided, when the managed economy contracted, the principle of uninterrupted maintenance of economy by technocratic politicians failed too. They failed without any perceived alternative; the obvious reaction for the average politician was to tuck tail and run away from the policies that were no longer working-which is precisely what they did.

A second theoretical implication that might be made based on our study of the S\&L market was that, for those who primarily identify themselves with the left, we are given only choices between stagnation and deprivation as it manifests itself within the, so-called, neoliberal regulatory system, on the one hand, or failed policies which fetishize capital and fantasize about constant-growth on the other. Discourses surrounding neoliberalism often only pit current regulatory regimes against failed Keynesian ones. Our only two theoretical alternatives have both returned unsatisfactory results.

A final theoretical implication to be made would be that there are other outlets toward development that are not proffered by either the discourses surrounding Keynesianism or anti-neoliberalism. The perspective that Keynesianism fell apart because of its internal contradictions and that neoliberalism was a haphazard response to this collapse can really shape future research perspectives. Not only that, but the argument and view that I am presenting here also has implications for societies at large as it considers a path forward. In other words, we can build a different structure. We do not have to go back to the past and Keynesianism, we can look into the future and propose a new alternative to neoliberalism. The general public, as well as policymakers, need to remember that the beginnings of what eventually became the S\&L structure, the thrifts, generally, began in the backrooms of saloons and parlors. Saving and Loans were not for profit, they were cooperative in nature. Immigrants, often illiterate, were responsible for the creation of an entire housing system built around the concepts of democracy, community, and participation - and they did so with pennies. It is this, not Keynesianism, not anti-neoliberalism, which should frame our discussions of potential pathways.

Funding: This research received no external funding.

Conflicts of Interest: The authors declare no conflict of interest.

\section{References}

1. Berry, M. Neoliberalism and the City: Or the Failure of Market Fundamentalism. Hous. Theory Soc. 2014, 31, 1-18. [CrossRef]

2. Feliciantonio, C.D.; Aalbers, M.B. The Prehistories of Neoliberal Housing Policies in Italy and Spain and Their Reification in Times of Crisis. Hous. Policy Debate 2018, 28, 135-151. [CrossRef]

3. Gillespie, T. Collective Self-Help, Financial Inclusion, and the Commons: Searching for Solutions to Accra's Housing Crisis. Hous. Policy Debate 2018, 28, 64-78. [CrossRef]

4. Wyly, E.K. Why (Not a Right to) Housing? Hous. Policy Debate 2013, 23, 29-34. [CrossRef] 
5. Dodson, J. The 'Roll' of the State: Government, Neoliberalism and Housing Assistance in Four Advanced Economies. Hous. Policy Debate 2006, 23, 224-243. [CrossRef]

6. Flanagan, K. A Genealogy of Public Housing Production: Practice, Knowledge and the Broadacre Housing Estate. Hous. Policy Debate 2015, 32, 407-428. [CrossRef]

7. Brenner, N.; Peck, J.; Theodore, N. After Neoliberalization? Globalizations 2010, 7, 327-345. [CrossRef]

8. Panitch, L.; Albo, G.; Chibber, V. Socialist register 2011: The Crisis This Time; Merlin Press: London, UK, 2010.

9. Fouskas, V.K.; Gökay, B. The Disintegrative and Authoritarian Logics of Euro-Atlanticism. In The Disintegration of Euro-Atlanticism and New Authoritarianism: Global Power-Shift; Fouskas, V.K., Gökay, B., Eds.; Springer International Publishing: Cham, Switzerland, 2019; pp. 149-182. [CrossRef]

10. Cole, I. Hidden from history? Housing studies, the perpetual present and the case of social housing in Britain. Hous. Stud. 2006, 21, 283-295.

11. Stilwell, F. Neoliberalism in the City: Economic Theory, Class Interests and Political Practices. Hous. Theory Soc. 2014, 31, 42-47. [CrossRef]

12. Thorsen, D.E.; Lie, A. What Is Neoliberalism? 2006. Available online: http://folk.uio.no/daget/What\% 20is\%20Neo-Liberalism\%20FINAL.pdf (accessed on 17 January 2019).

13. Harvey, D. A Brief History of Neoliberalism; Oxford University Press: New York, NY, USA, 2005.

14. Hayek, F.A. The Road to Serfdom; University of Chicago Press: Chicago, IL, USA, 1944.

15. Klein, N. The Shock Doctrine: The Rise of Disaster Capitalism; Metropolitan Books: New York, NY, USA, 2007.

16. Tabb, W.K. The Long Default: New York City and the Urban Fiscal Crisis; Monthly Review Press: New York, NY, USA; London, UK, 1982.

17. Stiglitz, J. Globalization and Its Discontents; Norton: New York, NY, USA, 2002.

18. Peck, J.; Theodore, N. Fast Policy: Experimental Statecraft at the Thresholds of Neoliberalism; U of Minnesota Press: Minneapolis, MN, USA, 2015.

19. Sauer, T.; Scholl, R. (Eds.) The Philosophy of Historical Case Studies, 2016 ed.; Softcover Reprint of the Original 1st ed; Springer: Berlin, Germany, 2018.

20. Giddens, A. The Constitution of Society: Outline of the Theory of Structuration; University of California Press: Berkeley, CA, USA, 1986.

21. Rosenthal, H.S. Manual for Building and Loan Associations; Rosenthal \& Company: Cincinnati, OH, USA, 1891.

22. Dexter, S. Co-Operative Savings and Loan Associations. Q. J. Econ. 1889, 3, 315-335. [CrossRef]

23. Morman, J.B. Coöperative Credit Institutions in the United States. Ann. Am. Acad. Polit. Soc. Sci. 1920, 87, 172-182. [CrossRef]

24. Clark, H.F. The Extension of State Regulation to the Building and Loan Association. J. Polit. Econ. 1924, 32, $621-647$. [CrossRef]

25. Abbott, A. From Causes to Events: Notes on Narrative Positivism. Sociol. Methods Res. 1992, $20,428-455$. [CrossRef]

26. Griffin, L.J. Temporality, events, and explanation in historical sociology: An introduction. Sociol. Methods Res. 1992, 20, 403-427. [CrossRef]

27. Marx, K. A Contribution to the Critique of Political Economy; Progress Publishers: Moscow, Russia, 1977.

28. Ferguson, C.H.; Audrey, M.; Chad, B.; Adam, B.; Matt, D.; Paul, A.V.; George, S. 2010 Inside job. Documentary, Crime; Sony Pictures Classiscs: Los Angeles, CA, USA, 2010.

29. Barth, J.R. The Great Savings and Loan Debacle; The AEI Press: Lanham, MD, USA; London, UK, 1991.

30. Barth, J.R.; Brumbaugh, R.D. Turmoil among depository institutions: Implications for the U.S. real estate market. Hous. Policy Debate 1992, 3, 901-926. [CrossRef]

31. Pyle, D.H. The U.S. Savings and Loan Crisis. In Finance, Handbooks in Operations Research and Management Science; Jarrow, R., Maksimovic, V., Ziemba, W.T., Eds.; Elsevier: Amsterdam, The Netherland, 1995; Volume 9, pp. 1105-1126.

32. Brown, M.W. The Development of Thrift; The Macmillan Company: New York, NY, USA, 1899.

33. Mason, D.L. From Building and Loans to Bail-Outs: A History of the American Savings and Loan Industry; Cambridge University Press: Cambridge, UK; New York, NY, USA; Melbourne, Australia; Madrid and Cape Town, Spain, 2004.

34. Stone, M.E. Pernicious Problems of Housing Finance. In A Right to Housing: Foundation for a New Social Agenda; Bratt, R.G., Stone, M.E., Hartman, C., Eds.; Temple: Philadelphia, PA, USA, 2006; pp. 82-104.

35. García, I. Symbolism, Collective Identity, and Community Development. Societies 2018, 8, 81. [CrossRef] 
36. Clarke, S. Overaccumulation, Class Struggle and the Regulation Approach. Cap. Class 1988, 12, 59-92. [CrossRef]

37. Krippner, G.R. Capitalizing on Crisis: The Political Origins of the Rise of Finance; Harvard University Press: Cambridge, MA, USA; London, UK, 2011.

38. Fabrice, C.; Dellas, H. The Great Inflation of the 1970s; Federal Reserve Bank: Washington, DC, USA, 2004. Available online: https://www.federalreserve.gov/pubs/ifdp/2004/799/ifdp799.htm (accessed on 19 January 2019).

39. Blanchard, O.J. The Wage Price Spiral. Q. J. Econ. 1986, 101, 543-566. [CrossRef]

40. Sherman, H.J. Theories of Cyclical Profit Squeeze. Rev. Radic. Polit. Econ. 1997, 29, 139-147. [CrossRef]

41. Federal Deposit Insurance Corporation. History of the Eighties-Lessons for the Future; Federal Deposit Insurance Corporation: Washington, DC, USA, 1997; Volume 1.

42. Kane, E.J. The High Cost of Incompletely Funding the FSLIC Shortage of Explicit Capital. J. Econ. Perspect. 1989, 3, 31-47. [CrossRef]

43. Thomson, J.B. Using Market Incentives to Reform Bank Regulation and Federal Deposit Insurance. Fed. Reserve Bank Clevel. Econ. Rev. 1990, 26, 28-40.

44. Veblen, T. The Theory of the Leisure Class; Oxford University Press: Oxford, UK, 2009.

45. García, I. Paseo Boricua. Identity, Symbols, and Ownership. América Crítica 2017, 1, 117-138. [CrossRef]

(c) 2019 by the author. Licensee MDPI, Basel, Switzerland. This article is an open access article distributed under the terms and conditions of the Creative Commons Attribution (CC BY) license (http://creativecommons.org/licenses/by/4.0/). 